$\underline{\text { Original Articles }}$

\title{
Distribution of different PML/RAR $\alpha$ bcr Isoforms in Indian Acute Promyelocytic Leukemia (APL) Patients and Clinicohematological Correlation
}

\author{
Tathagata Chatterjee ${ }^{1}$, Srishti Gupta ${ }^{2}$, Sanjeevan Sharma ${ }^{3}$ and Prosenjit Ganguli ${ }^{4}$ \\ 1 Professor \& Head of Department, Department of Immunohematology and Transfusion Medicine, Armed Forces \\ Medical College, Pune, India. \\ ${ }^{2}$ Senior Resident, Department of Pathology, NDMC Medical College, Delhi, India. \\ ${ }^{3}$ Associate Professor, Department of Haematology, Army Hospital(R \& R, Delhi, India. \\ ${ }^{4}$ Associate Professor, Department of Pathology, Army Hospital(R \& R), Delhi, India.
}

Correspondence to: Col Tathagata Chatterjee MD MNAMS DM FUICC FISHTM, Professor \& Head, Department of Immunohematology \& Transfusion Medicine, Armed Forces Medical College, Pune - 411040, India. Mobile number: 91-8551910936. Email: ctathagat@hotmail.com

Competing interests: The authors have declared that no competing interests exist.

Published: Published, January 2, 2014

Received: N0vember 11, 2013

Accepted: December 13, 2013

Citation: Mediterr J Hematol Infect Dis 2014, 6(1): e2014004, DOI: 10.4084/MJHID.2014.004

This article is available from: http://www.mjhid.org/article/view/12460

This is an Open Access article distributed under the terms of the Creative Commons Attribution License (http://creativecommons.org/licenses/by/2.0), which permits unrestricted use, distribution, and reproduction in any medium, provided the original work is properly cited.

Abstract. Context: Acute promyelocytic leukemia (APL), an AML subtype, is characterized morphologically by abnormal promyelocytes. Molecular studies show three possible bcr isoforms of PML-RAR $\alpha$ fusion gene. This study undertakes analysis of PML-RAR $\alpha$ bcr isoforms and their correlation with haematological parameters and response to treatment in Indian patients.

Aims: To study different PML-RAR $\alpha$ bcr isoforms in Indian patients and to find any correlation with various haematological parameters and response to treatment

Settings and Design: Patients diagnosed as APL on morphology or flowcytometry and confirmed by RQ PCR were included in the study. Treated APL patients or patients with relapse and on followup were excluded from the study.

Methods and Material: Twenty patients over thirty one months period were included. The clinical, haematological \& morphological features were analysed, the latter using routine \& special cytochemical stains on blood and bone marrow.

Flow cytometric evaluation using 4-color Beckman Coulter FC 500 and molecular studies using RT PCR Fusion Quant ${ }^{\circledR}$ kits for bcr-1, bcr-2 and bcr-3 of PML- RAR $\alpha$ bcr isoforms on the instrument Rotor GeneTM 3000 were performed.

Statistical analysis used: Student $t$ test was applied to correlate different bcr isoforms with various haematological parameters and response to treatment.

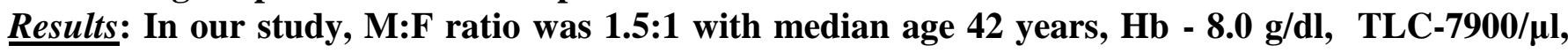
and platelet $-35000 / \mu \mathrm{l}$ and varied clinical presentation. Four patients were microgranular variants, and the rest were hypergranular. MPO and CAE positivity were100\% and for NSE it was 
33.33\%. Molecular analysis revealed PML-RAR $\alpha$ isoforms of bcr1 in $42.85 \%$, bcr2 in $14.28 \%$ and bcr3 in $\mathbf{3 8 . 0 9 \%}$ patients. No correlation was found between PML-RAR $\alpha$ bcr isoforms, different haematological parameters and response to treatment.

Conclusions: Higher incidence of PML- RAR $\alpha$ bcr-1 isoform was found in Indian APL patients with no significant correlation between different haematological parameters and response to treatment.

Introduction. Acute promyelocytic leukemia is a distinct subtype of acute myeloid leukemia (AML), which occurs in 5-13\% of patients diagnosed with AML. ${ }^{1-3}$ Morphologically the bone marrow shows effacement by heavily granulated cells with folded twisted nuclei. Cytogenetically, it is characterized by balanced reciprocal translocation between chromosome 15 and 17 which results in fusion between promyelocytic leukemia (PML) gene and Retinoic acid receptor $\alpha(\mathrm{RAR} \alpha)$ gene. ${ }^{1}$

There are 3 possible PML-RAR $\alpha$ isoforms caused by these translocations. The breakpoint in chromosome 17 is consistently found in intron 2, but varies in chromosome 15. The 3 breakpoints on the PML gene can occur at intron 3 (L-long form), intron 6 (S-short form), and exon 6 (V form). ${ }^{4-6}$ It has been reported that the $\mathrm{S}$ (short) form is associated with a shorter remission duration and overall survival compared with the $\mathrm{L}$ form in a study by Gonzales et al.. ${ }^{5}$ This translocation can be detected by karyotyping or fluorescence in situ hybridization (FISH) studies, and the transcript can be detected by molecular techniques like the polymerase chain reaction (PCR) techniques. The distribution of the breakpoint sites in the PML gene has been reported in several studies from Europe and USA to be approximately 50-55\% for PML (L) - RAR $\alpha, 8-20 \%$ for PML (V)-RAR $\alpha$ and 27-49\% for PML (S)-RAR $\alpha{ }^{7}$ In a study by Dutta et al from India ber 3 was found to be predominant. ${ }^{8}$

Reports suggesting an association between different PML- RAR $\alpha$ bcr breakpoint sites and clinical characteristics or response to treatment in APL patients have not been consistent. ${ }^{5-7}$

This study was undertaken to study the predominant PML-RAR $\alpha$ bcr isoform in Indian population and to study clinical-haematological profile.

Subjects and Methods. We analyzed twenty APL patients confirmed by RQ-PCR in the study during the period March 2010 to September 2012. All the patients fulfilled morphologic criteria for APL (Hypergranular and microgranular variant) as classified by WHO classification. ${ }^{9}$ In addition, all patients manifested the $\mathrm{PML} / \mathrm{RAR} \alpha$ rearrangements by RQ PCR. Patients with presumptive morphologic diagnosis but negative molecular result were excluded from this study. Clinical features, hematological parameters
[Hemoglobin (Hb), total leukocyte count (TLC), platelet count, prothrombin time and activated partial thromboplastin time, D-dimer and fibrinogen] were analyzed at presentation. Patients were grouped under low risk group (TLC $<10,000 / \mu 1$, platelet $>40,000 /$ $\mu \mathrm{l})$, intermediate risk group (TLC $<10,000 / \mu 1$, platelet count $<40,000 / \mu \mathrm{l}$ ) and high risk group (TLC $>10,000 /$ $\mu \mathrm{l}){ }^{10}$

Peripheral blood and bone marrow aspirate were stained with Leishman stain and cytochemistry consisted of myeloperoxidase (MPO), Chloroacetate esterase (CAE) and non-specific esterase (NSE) using Merck's ${ }^{\circledR}$ Diagnostic reagents and manufacturer specified staining instructions.

Flow cytometric evaluation was done on bone marrow aspirate using Beckman Coulter FC 500 four colour flowcytometer using standard Lyse wash technique. It was done on eleven patients only due to nonavailability of reagents. Antibodies used were labelled with FITC,PE,ECD and PC-5. Antibody panel used was CD13, CD33, CD45, cMPO, cCD79a, cCD3, CD15, HLA-DR, CD10, CD19, CD34, CD7, CD117 and sCD3.Antibody was considered positive if more than $20 \%$ of cells gated were positive. Sample was processed within 24 hours of collection. Gating strategy used was CD45 vs. SSC.

Samples were outsourced for cytogenetic evaluation due to lack of facilities in the centre for balanced reciprocal translocation between chromosome 15 and chromosome 17.

For molecular studies, peripheral blood sample was collected. RQ PCR was done for PML-RAR $\alpha$ fusion transcript. RNA was extracted and converted to cDNA using Applied Biosystems ${ }^{\circledR}$ High Capacity cDNA Reverse transcription kit on the same day of RNA extraction. cDNA was amplified using Fusion Quant ${ }^{\circledR}$ kits for PML (L)-RAR $\alpha$, PML (V)-RAR $\alpha$ and PML(S)RAR $\alpha$ on the instrument Rotor Gene 3000 as per the manufacturer's instructions. ABL transcript was used as an endogenous control gene. Water was used as a negative control. The test samples were run in duplicate.

RQ - PCR was carried out using Taqman $\AA$ universal PCR Master Mix and IPSOGEN® Primers and probe mix. Three different probes and primers were run for PML (L) - RAR $\alpha$, PML (V)-RAR $\alpha$ and PML(S)-RAR $\alpha$ all of which had separate kits. The kit 
used for PMLRARA@ is a quantitative individual primer based one and not multiplexes. Unfortunately, the only kit available as a multiplex one in our country is a qualitative one. The kit used in our dept is tabulated below.

\begin{tabular}{|c|c|}
\hline CODE & \multicolumn{1}{|c|}{ QIAGEN Kit NAME } \\
\hline 672123 & ipsogen $^{\circledR}$ PML-RARA bcr1 Kit (24) CE \\
\hline 672213 & ipsogen $^{\circledR}$ PML-RARA bcr2 Kit (24) \\
\hline 672313 & ipsogen $^{\circledR}$ PML-RARA bcr3 Kit (24) \\
\hline
\end{tabular}

The standards of each are labelled as F1, F2, F3, F4, F5. These have $10,100,1000,100,000$ and $10,00,000$ copies/5ul respectively.

Initially, we ran control gene, in our case $\mathrm{ABL}$ gene which has three standards C1, C2, C3 of 1000, 10,000 and 100,000 copies/5ul respectively. If these were in acceptable range then we proceeded for $\operatorname{PML}(\mathrm{L})$ RAR $\alpha$, PML(V)-RAR $\alpha$ and PML(S)-RAR $\alpha$ separately along with their 5 standards in a single Real time Q PCR and not multiplex.

Total number of cycles run was 45 cycles over a period of 2 hours and 20 minutes. Standard curves were obtained for control gene, fusion gene of standard and test samples after acquisition

The Control Gene (CG) standard curve equation was used to transform raw cycle threshold $(\mathrm{Ct})$ values obtained with Primer \& Probe Mix for Control gene (CG- PPC) for the unknown samples, into the CG copy numbers $(\mathrm{CG} \mathrm{CN})$.

The Fusion Gene standard curve equation was used to transform raw $\mathrm{Ct}$ values (obtained with Fusion gene Primer \& Probe Mix (FG- PPF) for the unknown samples into Fusion Gene copy numbers (FG CN). The ratio of these copy numbers gives the normalized copy number $(\mathrm{NCN})$ :

\section{$\mathrm{NCN}=\mathrm{FG} \mathrm{CN} / \mathrm{CG} \mathrm{CN}$}

Any value of normalized copy number above zero was considered as significant.

Table 1

\begin{tabular}{|c|c|}
\hline Induction & $\begin{array}{l}\text { - ATRA - } 45 \mathrm{mg} / \mathrm{m}^{2} \text { oral daily till } \\
\text { maximum } 60 \text { days } / \text { haematological } \\
\text { remission } \\
\text { - Injection Idarubicin } 12 \mathrm{mg} / \mathrm{m}^{2} \text { once } \\
\text { daily (D-1 to D-3) concomitantly }\end{array}$ \\
\hline $\begin{array}{l}\text { Consolidation } \\
\text { (2-3 cycles depending } \\
\text { upon risk } \\
\text { stratification) }\end{array}$ & $\begin{array}{l}\text { - Injection Idarubicin } 12 \mathrm{mg} / \mathrm{m}^{2} \text { daily } \\
\text { for } 3 \text { days } \\
\text { - ATRA } 45 \mathrm{mg} / \mathrm{m}^{2} \text { once daily for } 15 \\
\text { days }\end{array}$ \\
\hline Maintenance & $\begin{array}{l}\text { - } 3 \text { monthly cycles x } 6 \text { cycles } \\
\text { - } 3 \text { monthly cycle- } \\
\text { Day 1- } 15 \text { :ATRA } 45 \mathrm{mg} / \mathrm{m}^{2} \text { in two } \\
\text { divided doses } \\
\text { Tab 6- Mercaptopurine } 90 \mathrm{mg} / \mathrm{m}^{2} \\
3 \text { weeks/month } \\
\text { Tab Methotrexate } 15 \mathrm{mg} / \mathrm{m}^{2} \text { once a } \\
\text { week x } 3 \text { weeks } / \mathrm{month}\end{array}$ \\
\hline
\end{tabular}

Patients were treated with all Trans retinoic acid (ATRA) based regimen. Consolidation strategies adopted in our Institute depended on the risk classification for relapse at diagnosis. Two or 3 cycles of anthracycline-based chemotherapy were administered for low- and intermediate-risk patients in first complete remission (CR1) as shown in table 1. For patients with high-risk disease (WBC $>10000 / \mu \mathrm{L})$, either intermediate- or high-dose Ara-C was administered depending on age as a first consolidation as done in the GIMEMA APL 2000 study or ATO for 2 courses of 25 days each as carried out in the second North American Intergroup C9710 study.

Results. Twenty patients were studied. Patient characteristics are given in table 2 . The presenting clinical features are given in table 3 .

On morphological analysis, four patients were microgranular variants and sixteen were hypergranular. MPO and CAE stains were seen positive in $100 \%$ of APL cases, and NSE was seen in $33.33 \%$ of cases. Flowcytometric analysis of eleven patients [microgranular- n (2), hypergranular-n (9)] revealed characteristic findings of APL [11]. All hypergranular variants revealed a high side scatter and antigenic expression of CD13, CD33 and MPO. CD117 was expressed in one hypogranular and two hypergranular variants. Weak CD34 expression was seen in two hypogranular variants. HLA-DR expression was not seen in any case. Weak CD15 was noted in three hypergranular variants.

All the patients were cytogenetically determined to be characteristic t $(15 ; 17)$ (q22; q21).

Molecular analysis revealed PML(L) RAR $\alpha$ in 42.85\%, PML(V) RAR $\alpha$ in $14.28 \%$ and PML(S) RAR $\alpha$ in $38.09 \%$ patients. Amongst these, two microgranular

Table 2. Patient Characteristics

\begin{tabular}{|l|l|}
\hline No. of patients & 20 \\
\hline M:F ratio & $1.5: 1$ \\
\hline Median age & 42 years(Range $14-62$ years) \\
\hline Median Hemoglobin & $8.0 \mathrm{~g} / \mathrm{dl}($ Range $4.5-10.8 \mathrm{~g} / \mathrm{dl}$ ) \\
\hline $\begin{array}{l}\text { Median Total leukocyte } \\
\text { count }\end{array}$ & $7900 / \mu \mathrm{l}$ (Range $3000-71000 / \mu \mathrm{l})$ \\
\hline Median platelet count & $35000 / \mu \mathrm{l}$ (Range $10,000-52,000 / \mu \mathrm{l})$ \\
\hline Median PT & $\begin{array}{l}17.4 \text { seconds (Range } 14.2-23 \\
\text { seconds) } \\
\text { (PT control - } 13 \text { seconds) }\end{array}$ \\
\hline Median Aptt & $\begin{array}{l}40.1 \text { seconds (Range } 34.1-47 \\
\text { seconds) } \\
(\text { aPTT control - 40.1 seconds) }\end{array}$ \\
\hline Median D-dimer & $\begin{array}{l}5.3 \mu \mathrm{g} / \mathrm{ml}(\text { Range } 0.8-8.1 \mu \mathrm{g} / \mathrm{ml}) \\
(\text { Normal value }<0.5)\end{array}$ \\
\hline Median fibrinogen & $98 \mathrm{mg} / \mathrm{dl}($ Range $80-312 \mathrm{mg} / \mathrm{dl}$ ) \\
& Normal value $100-400 \mathrm{mg} / \mathrm{dl}$ ) \\
\hline Low risk group & 2 patients \\
\hline Intermediate risk group & 9 patients \\
\hline High risk group & 9 patients \\
\hline
\end{tabular}


Table 3

\begin{tabular}{|l|l|l|l|l|l|l|l|}
\hline Isoforms & $\begin{array}{l}\text { Total } \\
\text { patients(n) }\end{array}$ & Pallor & Fever & $\begin{array}{l}\text { Loss of } \\
\text { appetite }\end{array}$ & $\begin{array}{l}\text { Bleeding } \\
\text { manifestations } \\
\text { n }\end{array}$ & $\begin{array}{l}\text { Gum } \\
\text { hypertrophy }\end{array}$ & DIC \\
\hline PML(L)-RAR $\alpha$ & 9 & $100 \%(9)$ & $55.55 \%(5)$ & $33.33 \%(3)$ & $44.44 \%(4)$ & Nil(0) & $44.44 \%(4)$ \\
\hline PML(V)-RAR $\alpha$ & 3 & $100 \%(3)$ & $100 \%(3)$ & Nil(0) & $100 \%(3)$ & $33.33 \%(1)$ & $66.66 \%(2)$ \\
\hline PML(S)-RAR $\alpha$ & 8 & $100 \%(8)$ & $100 \%(8)$ & $62.5 \%(5)$ & $62.50 \%(5)$ & $37.50 \%(3)$ & $62.50 \%(5)$ \\
\hline
\end{tabular}

variants were PML(L) RAR $\alpha$ positive, third microgranular variant was PML(V) RAR $\alpha$ and the fourth PML(S) RAR $\alpha$ positive. Five patients died during the induction phase of which three were PML(S) RAR $\alpha$ positive and two were PML(L) RAR $\alpha$ positive. Three patients died due to intracranial haemorrhage, and two patients died due to hyperkalemia leading to cardiac arrest. Rest of the patients achieved molecular remission. No significant correlation was found between PML-RAR $\alpha$ bcr isoforms, age, sex and different haematological parameters namely haemoglobin, total leukocyte count, platelet count and response to treatment.

Discussion. On examination, one unusual feature was gum hypertrophy seen in four patients (20\%). This observation is similar to a previous Indian study by Dutta et al. ${ }^{8}$ where the same clinical feature was observed in some of their patients. However unlike that study not a single case of ours presented with scrotal ulceration. We feel that presence of gum hypertrophy seen commonly in acute myelomonocytic leukemia is also seen in Indian APL patients. Generally, gum hypertrophy is very rarely seen in AML-M3. ${ }^{12}$ Another unusual feature was high TLC at presentation. TLC varied from $3000 / \mu \mathrm{l}$ to $71,000 / \mu \mathrm{l}$ with a median of $7900 / \mu 1$. APL is characterised by pancytopenia in peripheral blood. Raised TLC is seen in 10-30\% of cases especially with microgranular variant. ${ }^{12}$ In our series of twenty patients, four were microgranular variants (20\%). Three out of four patients of microgranular variants showed high TLC at presentation. Statistical significance was not determined due to the small number of cases.

Cytochemistry results showed positivity for MPO and CAE in all the APL cases (100\%).Interestingly $33.33 \%$ of cases also showed positivity for NSE. This finding is in concordance with previous published literature where NSE positivity in APL cases is between $13.5 \%-60.7 \% .^{8,13}$

RQ-PCR done at the time of diagnosis revealed PML-RAR $\alpha$ transcript in twenty patients. Unusual feature was that in our study PML(L) RAR $\alpha$ isoform was found to be the predominant isoform (42.85\%) followed by PML(S) RAR $\alpha$ isoform (38.09\%). Whereas according to data published in India by Dutta et al. ${ }^{8}$ PML(S) RAR $\alpha$ isoform was found to be significantly high $(72.7 \%)$. However, our study results were in concordance with published western studies. ${ }^{7}$ In a study of 2003 Douer et al. ${ }^{7}$ found a frequency of PML(L) RAR $\alpha$ isoform significantly high. They summarized also the distribution of the breakpoint sites in the PML gene reported in several studies from Europe and the USA, which was approximately 50$55 \%$ for PML(L) RAR $\alpha, 8-20 \%$ for PML(V) RAR $\alpha$ and $27-49 \%$ for $\operatorname{PML}(\mathrm{S})$ RAR $\alpha{ }^{7}$ This finding suggests that PML (L) RAR $\alpha$ subtype may represent a distinct biological subset and breakpoint at intron 6 in PML gene may not be a random event. This might be possibly related to genetic and/ or environmental factor(s) playing a role in determining the breakage site of the PML gene. Multicentre trial studies are needed to confirm the same.

Of total twenty patients in the study, five patients (25\%) died during the induction phase. Three were PML(S) RAR $\alpha$ positive and two were PML(L) RAR $\alpha$ positive. No mortality was noted with PML(V) RAR $\alpha$ isoform. In previous studies of cytotoxic chemotherapy, early deaths during induction in patients with APL occurred primarily as a consequence of intracranial hemorrhage. ${ }^{14,15}$ The hemorrhagic diathesis of APL is related to depletion of platelets and clotting factors, probably owing to leukemic cell lysis and release of procoagulant or fibrinolytic materials into the circulation. ${ }^{16,17}$ Early mortality from this problem has ranged from $10 \%$ to $47 \%$ in published series. ${ }^{18,19}$ According to published studies PML(S) RAR $\alpha$ isoform has been related to inferior duration of remission and overall survival. $^{20}$

All our 15 patients are under regular follow-up. There is a system in the Indian Armed Forces patients to compulsorily attend follow-up as per standard instructions of the Clinicians. A separate long-term follow-up study is being devised by our Clinical investigators for all APL patients and is likely to be published in two years time involving at least 50 patients; hence it will be beyond the scope of this particular publication to consider the over-all DFS, median FU and OS. However, regular follow-up is being meticulously recorded for all our fifteen APL patients.

No significant correlation was found between the PML-RAR $\alpha$ isoforms, haematological parameters, age, sex and response to treatment; however study involving a small sample size may not have the power to detect such a relationship. This is similar to results of 
previous studies. ${ }^{7,21}$ However some studies have found an association between PML(S) RAR $\alpha$ isoform and high TLC $^{22}$ and PML(V) RAR $\alpha$ isoform and high TLC at presentation. ${ }^{5}$

Conclusion. To conclude, APL is a distinct biological

\section{References:}

1. Rowley, J.D., Golomb, H.M. \& Dougherty, C. (1977) 15/17 Translocation, a consistent chromosomal change in acute promyelocytic leukaemia [letter]. Lancet, 1, 549-550 http://dx.doi.org/10.1016/S0140-6736(77)91415-5

2. Arthur, D.C., Berger, R., Golomb, H.M., Swansbury, G.J., Reeves, B.R., Alimena, G., et al (1989) The clinical significance of karyotype in acute myelogenous leukaemia. Cancer Genetics and Cytogenetics, 40, 203-216. http://dx.doi.org/10.1016/01654608(89)90025-3

3. Fenaux, P., Preudhomme, C., Lai, J.L., Morel, P., Beuscart, R. \& Bauters, F. (1989) Cytogenetics and their prognostic value in de novo acute myeloid leukaemia: a report on 283 cases. British Journal of Haematology, 73, 61-67 http://dx.doi.org/10.1111/j.1365-2141.1989.tb00221.x PMid:2803981

4. Grimwade D, Walker H, Oliver F, Wheatley K, Harrison C, Harrison G, et al. The importance of diagnostic cytogenetics on outcome in AML: analysis of 1,612 patients entered into the MRC AML 10 trial. The Medical Research Council Adult and Children's Leukaemia Working Parties. Blood 1998; 92 : 2322-33. PMid:9746770

5. Gonzalez M, Barragan E, Bolufer P, Chillon C, Colomer D, Borstein R et al. Pretreatment characteristics and clinical outcome of acute promyelocytic leukaemia patients according to PMLRARA isoforms: A study of PETHEMA group. $\mathrm{Br} \mathrm{J}$ Haematol 2001; $\quad 114: 99-103 \quad$ http://dx.doi.org/10.1046/j.13652141.2001.02915.x PMid:11472351

6. Gallagher, R.E., Willman, C.L., Slack, J.L., Andersen, J.W., Li, Y.P., Viswanatha, D.et al (1997) Association of PML-RAR alpha fusion mRNA type with pretreatment hematologic characteristics but not treatment outcome in acute promyelocytic leukemia: an intergroup molecular study. Blood, 90, 1656-1663 PMid:9269786

7. Douer D , Santillana S, Ramezani L, Samanez C, Slovak M. L. , Lee M. S. et al. Acute promyelocytic leukemia in patients originating in Latin America is associated with an increased frequency of the bcr 1 subtype of the PML/RAR $\alpha$ fusion gene. British Journal of Hematology 2003;122:563-570 http://dx.doi.org/10.1046/i.1365-2141.2003.04480.x

8. Dutta P, Sazawal S, Kumar R, Saxena R. Does acute promyelocytic leukemia in Indian patients have biology different from the west? Indian Journal of Pathology and Microbiology July- September 2008;51(3):437-439 http://dx.doi.org/10.4103/0377-4929.42555

9. Arber D. A., Brunning R.D., Le Beau M.M., Falini B., Vardiman J.W., Porwit A. et al. Acute myeloid leukemia with recurrent genetic abnormalities. In: Swerdlow S.H., Campo E, Harris N.L., Jaffe E.S., Pileri S.A., Stein H et al editors. WHO Classification of Tumours of Haematopoietic and Lymphoid Tissues. 4th ed.Lyon;IARC:pp112-114.

10. Sanz M.A., Lo Coco F, Martin G, et al. Definition of relapse risk and role of non-anthracycline drugs for consolidation in patients entity. In our study PML(L) RAR $\alpha$ isoform was found to be the predominant isoform (in concordance with western studies) followed by PML(S) RAR $\alpha$ isoform with no significant correlation with age, sex, haematological parameters and response to treatment. with acute promyelocytic leukemia: a joint study of the PETHEMA and GIMEMA cooperative groups. Blood 2000; 96:1247-1253 PMid:10942364

11. Nguyen D, Diamond L W, Braylan R C.FCM interpretation and reporting. In: Flowcytometry in Hematopathology : A Visual Approach to Data Analysis and Interpretation.2nd ed. New Jersey; Humana press: pp 292-293.

12. Soignet SL, Maslak PG. Acute promyelocytic leukemia. In Lippincott Williams and Wilkins.11th ed. Vol 2;2004:pp 2191 2206

13. Das Gupta A, Sapre RS, Shah AS , Advani SH, Nair CN Cytochemical and immunophenotypic heterogeneity in acute promyelocytic leukemia. Acta Haematol 1989;81:5-9 http://dx.doi.org/10.1159/000205390 PMid:2467498

14. Gralnick HR, Sultan C: Acute promyelocytic leukaemia:Haemorrhagic manifestation and morphologic criteria Br J Haematol;29:373, 1975 http://dx.doi.org/10.1111/j.13652141.1975.tb01834.x PMid:1059471

15. Stone RM, Mayer RJ: The unique aspects of acute promyelocytic leukemia. J Clin Oncol 8:1913, 1990 PMid:2230879

16. Marty M, Ganem G, Fischer J, Flandrin G, Berger R, Schaison G Degos L, Boiron M: Acute promyelocytic leukemia: A retrospective study of 119 patients treated by daunorubicin. Nouv Rev Fr Hematol 26:37 1, 1984

17. Ventura GJ, Hester JP, Dixon DO, Khorana S, Keating MJ: Analysis of risk factors for fatal hemorrhage during induction therapy of patients with acute promyelocytic leukemia. Hematol Pathol 3:23, 1989 PMid:2745357

18. Rodeghiereo F, Avvisati G, Castaman G, Barbui T, Mandelli F Early deaths and anti-hemorrhagic treatments in acute promyelocytic leukemia: A GIMEMA retrospective study in 268 consecutive patients. Blood 75:2112, 1990

19. Warrell RP Jr, de The H, Wang ZY, Degos L: Acute promyelocytic $\begin{array}{lllll}\text { leukemia. N Engl J Med 329:177, } 1993 & \end{array}$ http://dx.doi.org/10.1056/NEJM199307153290307 PMid:8515790

20. Vahdat L, Maslak P, Miller W H Jr, Eardley R, Heller G, Scheinberg DA et al.Early Mortality and the Retinoic Acid Syndrome in Acute Promyelocytic Leukemia: Impact of Leukocytosis, Low Dose Chemotherapy, PMN/RAR- $\alpha$ isoform, and CD13 Expression in patients treated with All- trans retinoic acid. Blood 1994; 84:3843-3849 PMid:7949141

21. Grimwade D, Howe K, Langabeer S, Davies L, Oliver F, Walker H et al. Establishing the presence of the $(15 ; 17)$ in suspected acute promyelocytic leukemia: Cytogenetic, molecular and PML immunofluorescence assessment of patients entered into the MRC ATRA trial.Br J Haematol 1996:94:557-573 PMid:8790159

22. Lo Coco F, Breccia M, Diverio D. The importance of molecular monitoring in acute promyelocytic leukemia. Best Pract Res Clin Haematol 2003;16:503-520 http://dx.doi.org/10.1016/S15216926(03)00041-0 